\title{
Specific Factors Affecting Nonperforming Loans from Banks in Member Countries of the Economic and Monetary Community of Central Africa (CEMAC)
}

\section{Elfy Deba Yanga Bangagnan}

Laboratory of Economic and Social Research and Studies (LARES), Faculty of Economics, Marien Ngouabi University, Brazzaville, Republic of the Congo

Email: elfybang311@gmail.com

How to cite this paper: Bangagnan, E. D. Y. (2021). Specific Factors Affecting Nonperforming Loans from Banks in Member Countries of the Economic and Monetary Community of Central Africa (CEMAC). Modern Economy, 12, 1782-1794. https://doi.org/10.4236/me.2021.1212091

Received: November 4, 2021

Accepted: December 11, 2021

Published: December 14, 2021

Copyright $\odot 2021$ by author(s) and Scientific Research Publishing Inc. This work is licensed under the Creative Commons Attribution International License (CC BY 4.0).

http://creativecommons.org/licenses/by/4.0/

\begin{abstract}
The banking system plays a significant role in economic activity. It connects agents with financial capacity and those with a need for funding. The objective of this study is to determine the specific factors that influence the nonperforming loans of CEMAC banks. This research covers the six (6) CEMAC countries over a period from 2004 to 2017. To achieve this objective, we used the dynamic ordinary least squares (DOLS) method. The obtained results show that factors such as the ratio of loans to total bank assets (RPA), return on assets (ROA) and the ratio of loans to deposits (RCD) increase nonperforming loans from CEMAC banks.
\end{abstract}

\section{Keywords}

Nonperforming Loans, Factors, Banks, DOLS, CEMAC

\section{Introduction}

Nonperforming loans have garnered great interest among researchers and policy-makers over the past four decades (Upal, 2009). Indeed, the increase in these loans causes banking crises that turn into bank failures (Barr, Seiford, \& Siems, 1994). In addition, nonperforming loans were considered to be one of the main causes of the global financial crisis (2007-2009), which affected the US economy and the economies of many countries (Adebola, Wan Yusoff, \& Dahalan, 2011). The magnitude of this crisis and its negative effects on some global economies have highlighted the need for researchers and monetary authorities to streng- 
then the management of nonperforming loans within banks. Indeed, the good functioning of the banking sector accelerates economic growth, while the poor functioning of the banking sector is an obstacle to economic progress and, therefore, aggravates poverty (Richard et al., 2011). The performance of the banking sector is a symbol of prosperity and economic growth in any country or region, and the poor performance of these institutions doesn't only hinder the economic growth and structure of a particular region but also affects the whole world (Khan, Senhadji, \& Smith, 2001). Based on the traditional role of the bank, it can be noted that loans constitute the bulk of bank assets (Njanike, 2009). Indeed, the interest on loans contributes significantly to the interest income of banks (Kamunge, 2013). Therefore, despite the importance of loans to banks in terms of assets and income, the lending process is not as straightforward as one might imagine. Loans oblige banks to assess the creditworthiness of borrowers and their ability to repay on time according to the contract established between the two parties. However, these steps do not always lead to a successful transaction, as one cannot know what will happen in the future. Consequently, the management of factors affecting the banking book has been the subject of numerous theoretical and empirical analyses.

At the theoretical level, there are two approaches suggesting different factors that can influence nonperforming loans. The first approach shows that nonperforming loans are tied to conditions in the economy. Indeed, during booms, the financial profile of borrowers improves, asset prices rise, and this euphoric situation paves the way for increased demand for credit (Gertler \& Bernanke, 1989; Pesaran, 2006). In contrast, the second approach considers that the increase in nonperforming loans is linked to the distinctive characteristics of the banking sector and to the political choice of individual banks, which exert a decisive influence on the increase in nonperforming loans (Berger \& De Young, 1997; Keeton et al., 2003).

Empirically, Louzis et al. (2012) show that nonperforming loans are explained mainly by external factors, which is contrary to the results of Ahmad and Bashir (2013), who explain the increase in nonperforming loans by internal factors. These differences call for new research to shed more light on this debate, in particular by taking into account little-explored fields of investigation, such as that of the CEMAC, which may be a relevant field of research for at least three reasons.

First, the number of active banks increased from 30 to 52 between 2004 and 2017, an increase of 22 banks in 13 years, or an average of two (2) banks per year. This increase is expected to increase the competition between banks.

Then, according to COBAC reports, the deposits collected increased from 3,096,559 (in billion FCFA) to 9,934,504 (in billion FCFA), and in terms of credit distribution, the CEMAC banks granted loans amounting to 8106.788 billion CFAF in 2017 (COBAC, 2017) against 1711.623 billion CFAF in 2004 (COBAC, 2004 ), i.e., an increase of $373.63 \%$ between the two (2) years.

Finally, there is an exponential increase in bad debts, from 250.247 billion 
FCFA in 2004 (BEAC, 2004) to 1446.874 billion FCFA in 2017 (Banque de France, 2017). According to COBAC, bad debts consist of unpaid debts, fixed debts and bad debts. The magnitude of risk can weaken bank portfolios and contribute to bankruptcies. The theoretical and empirical contradiction, coupled with the salient facts about the CEMAC banking system, led us to the following question: What are the factors behind the nonperforming loans of CEMAC banks? In light of this question, this article aims to determine the factors affecting the nonperforming loans of CEMAC banks. Thus, based on the work of Ghosh (2015), this study postulates that internal bank factors contribute to the increase in nonperforming loans of CEMAC banks.

In addition to the introduction, this article is structured as follows. In the second section, we review the literature. The third section is devoted to the methodology. In the fourth section, we present and interpret the results. The conclusions and policy implications are presented in the fifth section.

\section{Literature Review}

The factors of nonperforming loans have been the subject of theoretical analyses and empirical evidence that fall into two groups: the first group concerns factors related to economic conditions, and the second group concerns factors related to the individual specificities of banks. Several works focus on the relationship between NPLs and macroeconomic factors (Salas \& Saurina, 2002; Nor et al., 2021). The latter that the literature suggests as being important determinants are: annual GDP growth, credit growth, real interest rate, annual inflation rate, real exchange rate, annual unemployment rate, the money supply (M2) and the GDP by capital. Besides the macroeconomics factors, several empirical studies suggest that bank-specific factors are important because they can trigger risky loans (Berger \& De Young, 1997; Keeton, 1999; Ahmad \& Bashir, 2013; Karadima \& Louri, 2021). These factors are such as the size of the institution, profitability, capital, intermediation rate, risk profile and market power.

For proponents of factors related to economic conditions (Nkusu, 2011; Beck et al., 2013), during boom periods, the financial profile of borrowers improves, asset prices rise, and this euphoric situation paves the way for an increase in demand for credit. On the other hand, nonperforming loans are doomed to increase in the event of a recession. Thus, according to Ozili (2015), "the state of the economy is the most important systematic factor influenced by the diversified loss rates of the loan portfolio".

Empirical research has been conducted to confirm the analyses of this group of authors. Mpofu and Nikolaidou (2018) study the macroeconomic determinants of nonperforming loans in the banking system of 22 economies in subSaharan Africa. They use dynamic panel data methods over the period 20002016. The results show that an increase in the growth rate of real GDP has a statistically and economically significant effect reducing the ratio of nonperforming loans to total gross loans. In addition, the rate of inflation, domestic bank credit 
to the private sector as a percentage of GDP, and openness of trade all have a positive and significant impact on nonperforming loans (NPLs). Likewise, Mazreku et al. (2018) study the influence of determinants of credit risk in countries in transition. They use dynamic panel fixed and random effects models over the period from 2006 to 2016. They find that GDP growth and inflation are both negatively and significantly correlated with the level of nonperforming loans and that unemployment is positively linked to these loans.

The second group dealing with factors linked to the specific individual conditions of banks, in contrast, is based on the lending behavior of individual banks (Berger \& Deyoung, 1997; Keeton et al., 2003). For these authors, the peculiarities of the banking sector and the political choices of each bank, especially with regard to their efforts to improve efficiency and risk management, are likely to influence the evolution of nonperforming loans. The actions of the borrower thus make it difficult to assess the creditworthiness of the borrower (Dell'Ariccia, 2001). Therefore, informational asymmetries cause adverse selection and moral hazard problems, which were first described by Akerlof (1970).

Empirical evidence has confirmed the analyses of this group. Ahmad and $\mathrm{Ba}$ shir (2013) find a positive relationship between credit growth and nonperforming loans. Likewise, Chimkono et al. (2016) apply the dynamic panel data method to examine the determinants of NPLs in the Malawian banking sector using a sample of 11 banks over the period 2008-2014. They claim that internal bank factors, such as the net cost/income ratio (general operating expenses/net banking income) and the average lending interest rate explain the high NPL rate of these banks.

Wanjala and Gachanja (2020) explore the determinants of nonperforming loans specific to Kenyan banks. Four bank-specific variables are considered. These variables are the size of the bank as measured by total assets, the loanto-deposit ratio, the capital adequacy ratio and the interest rate. They use a causal research plan. Time regression is applied to data from 43 Kenyan banks. This study reveals that there is a positive relationship between the size of the bank and NPLs. The authors also observe that there is a negative relationship between the loan-to-deposit ratio and nonperforming loans. They further find that there is a negative correlation between the capital adequacy ratio and NPLs in Kenya. Finally, the study establishes that there is a positive relationship between the interest rate and NPLs in Kenya.

This overview of the literature shows that most of the existing research on the determinants of nonperforming loans in the banking sector relates to developed countries (Skarica, 2014; Makri et al., 2014). This article aims to enrich the sparse literature on the determinants of nonperforming loans in the CEMAC banking sector.

\section{Methodology of Non-Performing Loan Factors}

This section describes the methodology for analyzing the factors that can influ- 
ence the nonperforming loans of CEMAC banks. Thus, the model is designed based on previous work. Several studies focusing on the analysis of the determinants of credit risk build their model based on the literature. Indeed, Ansari and Benabdellah (2017) in Moroccan banks and Rachman et al. (2018) in Indonesian banks emphasize the regression function in fixed-effects panel data. Their analyses focus on the factors behind nonperforming bank loans. They assume that there is a linear relationship between nonperforming loans and the variables used in their research. However, all these authors consider the ratio of nonperforming loans as the dependent variable and the variables specific to banks as independent variables.

Several specifications exist, but in this study, we start with the models presented by different authors to specify the relation of concern. This specification is represented by Equation (1) below:

$$
y_{i t}=\gamma_{i}+\beta V_{i t}+\varepsilon_{i t}
$$

where $y_{i t}$ is the endogenous variable, representing nonperforming loans expressed as a proportion of bad debts on loans granted, and $V_{i t}$ represents the vector of exogenous variables that can affect nonperforming loans. Index $i$ designates the country, index $t$ indicates the time, $\gamma_{i}$ is a constant, $\beta$ is the coefficient of the exogenous variables, and $\varepsilon_{i t}$ is the error term. Thus, by considering the variables retained for this study, the specification of the empirical model is presented in the following lines.

Hereafter, the reformulation of the specific factors of nonperforming loans will be specified as in Equation (2) below:

$$
P N F_{i t}=\beta_{0}+\beta_{1} R O A_{i t}+\beta_{2} R F A_{i t}+\beta_{3} R P A_{i t}+\beta_{4} R C D_{i t}+\varepsilon_{i t}
$$

In this equation, $\beta$ are the parameters of interest to be estimated, and indices $i$ and $t$ indicate the country considered and the year of observation, respectively.

$P N F_{i t}$ : Ratio of nonperforming loans to total loans from banks in country $i$ in period $t$;

$R O A_{i t}$ : Return on assets of banks in country $i$ in period $t$;

$R F A_{i t}$ : Ratio of equity to total assets of banks in country $i$ in period $t$;

$R P A_{i t}$ : Ratio of loans to total assets of banks in country $i$ in period $t$,

$R C D_{i t}:$ Intermediation ratio of country $i$ at period $t$,

$\varepsilon_{i t}$ : The error term;

$\beta_{0}$ : The constant;

$\beta_{1}, \beta_{2}, \beta_{3}, \beta_{4}, \beta_{5}$ : The settings.

\section{1) Definition of variables}

The choice of variables and the period studied is made on the basis of previous research (Yanga, 2020) and the availability of data over the period 2004-2018. To identify the bank-specific factors of nonperforming loans, all available variables that most closely match those used in the empirical literature were identified. Thus, the variables retained in the context of this study are described in Table 1. 
Table 1. Definition of variables.

\begin{tabular}{|c|c|c|c|c|}
\hline $\begin{array}{c}\text { Name of } \\
\text { the variable }\end{array}$ & Code & Measure & Formula & $\begin{array}{l}\text { Unit of } \\
\text { measure }\end{array}$ \\
\hline $\begin{array}{l}\text { Nonperforming } \\
\text { loans }\end{array}$ & PNP & $\begin{array}{l}\text { Nonperforming } \\
\text { loan ratio }\end{array}$ & $\frac{\text { Non performing loans }(\mathrm{t})}{\text { Total of credits }(\mathrm{t})}$ & Percentage \\
\hline Return & ROA & $\begin{array}{l}\text { Return } \\
\text { of assets }\end{array}$ & $\frac{\text { Net result }(\mathrm{t})}{\text { Total of assets }(\mathrm{t})}$ & Percentage \\
\hline Capital & RFA & $\begin{array}{l}\text { Equity/asset } \\
\text { ratio }\end{array}$ & $\frac{\text { Total Equity }(\mathrm{t})}{\text { Total assets }(\mathrm{t})}$ & Percentage \\
\hline Banks risk & RPA & $\begin{array}{l}\text { Ratio of } \\
\text { loans/total } \\
\text { assets }\end{array}$ & $\frac{\text { Gross loans }(\mathrm{t})}{\text { Total assets }(\mathrm{t})}$ & Percentage \\
\hline $\begin{array}{l}\text { Intermediation } \\
\text { rate }\end{array}$ & $\mathrm{RCD}$ & $\begin{array}{l}\text { Credit/deposit } \\
\text { ratio }\end{array}$ & $\frac{\text { Total gross loans }(\mathrm{t})}{\text { Total des deposits }(\mathrm{t})}$ & Percentage \\
\hline
\end{tabular}

Source: Author from the literature review.

The choice of variables is important when using an econometric model. By referring to previous empirical work (Rachman et al., 2018), we defined the variables used in this study. Table 2 summarizes the description of the variables and expected signs.

Table 2. Summary of the literature on the determinants of bad debts in the banking sector.

\begin{tabular}{|c|c|c|c|}
\hline Variables & Description of variables & $\begin{array}{l}\text { Expected } \\
\text { sign }\end{array}$ & Previous work \\
\hline PNP & Nonperforming loan ratio & - & - \\
\hline \multirow{3}{*}{ ROA } & \multirow{3}{*}{ Return of des assets } & Negative & Louzis et al. (2012) \\
\hline & & Positive & Rajan (1994) \\
\hline & & Positive & Keeton (1999) \\
\hline \multirow{2}{*}{ RFA } & \multirow{2}{*}{ Capital } & Positive & Rajan (1994) \\
\hline & & Negative & Keeton \& Morris (1987) \\
\hline RPA & Ratio of loans to total assets & Positive & Sinkey \& Greenwalt (1991) \\
\hline $\mathrm{RCD}$ & Ratio of loans to deposits & Positive & $\begin{array}{c}\text { Swamy (2012); } \\
\text { Ahmad \& Bashir (2013) }\end{array}$ \\
\hline
\end{tabular}

Source: Author based on the authors' empirical work.

\section{2) Estimation procedure}

To highlight the Dynamic Ordinary Least Squares (DOLS) method, it is important to mention that the econometrics of non-stationary panel data includes methods

semi-parametric like Fully Modified Ordinary Least Squares (FM OLS) implemented by Pedroni (2000) and parametric methods such as ordinary least 
squares dynamics (DOLS, Dynamic Ordinary Least Squares) offered by Saikkonenn (1991); Stock and Watson (1993) in the time series, then adapted by Kao and Chiang (2001) for panel data. Thus, the latter focused on the finite sample properties of the estimators of OLS, FM-OLS and DOLS. They show that the estimate of small sample OLS cointegration relationship present a problem of bias and the corresponding statistical tests do not follow a usual Student's law. For this purpose, they propose to use the FM-OLS method initiated by Phillips and Hansen (1990) and the DOLS method. But the estimator DOLS is more efficient than FM-OLS and MCO for estimating the cointegration relation according to the simulations of Kao and Chiang (2001).

To identify the specific factors of nonperforming loans of CEMAC banks, we will use the dynamic least squares method. The choice of this method is justified by the fact that the DOLS estimator is more efficient than the fully modified ordinary least squares (FM-OLS) and ordinary least squares (OLS) estimators for the estimation of the cointegration relation according to the simulations (Kao \& Chiang, 2001). However, for estimation using panel data, it is necessary to carry out descriptive and correlational studies of the variables, test the dependence of variables, and consider the stationarity and cointegration relation of the variables.

\section{3) Data sources and descriptive analysis}

This study adopts a panel dataset from CEMAC banks over the period 2004-2018. This period is chosen according to the availability of data on nonperforming loans. The data come mainly from the COBAC reports, the reports of the franc zone and the BEAC. Table 3 lists the descriptive statistics of the variables used in this research.

Table 3. Descriptive statistics.

\begin{tabular}{ccccc}
\hline Variable & Mean & Standard deviation & Min & Max \\
\hline PNP & 13.012 & 8.362 & 1.386 & 34.565 \\
ROA & 1.599 & 1.759 & -1.842 & 14.660 \\
RFA & 0.086 & 0.0470 & 0.02608 & 0.3281 \\
RPA & 58.245 & 20.109 & 22.0944 & 177.622 \\
RCD & 71.233 & 28.498 & 25.9394 & 177.3103 \\
\hline
\end{tabular}

Source: Author's calculation.

Table 3 presents the descriptive statistics of the dependent variable and the independent variables. In this study, the total number of observations is 84 . Table 3 shows that the mean values of PNP, ROA, RFA, RPA and RCD are 13.01, $1.599,0.086,58.245$ and 71.233 , respectively. The standard deviation for PNP is 8.36 , with a minimum value of 1.38 and a maximum value of 34.56 . The minimum value of the intermediation rate is 25.93 , with a maximum value of 177.31 and a standard deviation of 28.49. However, the standard deviation of return on assets is 1.75 , with a minimum value of 1.84 and a maximum value of 14.66 . 


\section{4) Stationarity of variables}

The role assigned to the stationarity tests is to detect the existence of a trend (unit root) in distribution to determine the correct way to make a series that is not stationary, i.e., in case the existence of a unit root is revealed by the test. Table 4 implements the results of the stationarity tests.

Table 4. Results of stationarity tests.

\begin{tabular}{cccccccccccc}
\hline & \multicolumn{1}{c}{ PNP } & \multicolumn{2}{c}{ ROA } & \multicolumn{2}{c}{ RFA } & RPA & \multicolumn{2}{c}{ RCD } \\
\hline & \multicolumn{8}{c}{ Level variables } \\
\hline & Stat & Prob & Stat & Prob & Stat & Prob & Stat & Prob & Stat & Prob \\
\hline LLC & -6.759 & 0.000 & -5.107 & 0.000 & -0.255 & 0.399 & -4.173 & 0.000 & -1.990 & 0.023 \\
IPS & -1.443 & 0.073 & -3.055 & 0.001 & 1.476 & 0.930 & -3.970 & 0.000 & -1.200 & 0.115 \\
\hline & \multicolumn{1}{c}{ Variables in first difference } & & & \\
\hline & Stat & Prob & Stat & Prob & Stat & Prob & Stat & Prob & Stat & Prob \\
\hline LLC & -6.759 & 0.000 & -11.150 & 0.000 & -4.745 & 0.000 & -15.607 & 0.000 & -8.089 & 0.000 \\
IPS & -4.328 & 0.000 & -7.638 & 0.000 & -2.909 & 0.001 & -12.944 & 0.000 & -5.777 & 0.000 \\
\hline
\end{tabular}

Source: Author's calculation using EViews 9.

The analysis of the results of this table shows that for the two tests carried out, the variables are integrated in the first order. Thus, H0 suggesting stationarity is called into question given the existence of a unit root, supporting alternative $\mathrm{H} 1$. Indeed, $\mathrm{H} 1$ confirms the stationarity of the variables. Then, all the variables used here are stationarity in first difference and therefore integrated of order one [I (1)]. This means that to make the stationary of variables, it is important to differentiate them only once. Thus, the stationarity of the variables in the first difference makes it possible to understand the existence of a long-term cointegrating relation between the variables. However, this long-term relationship must be accepted through various tests called "cointegration tests".

Several tests are used to study stationarity in panel data (Ficher, Kao, Pedroni).

In the context of this study, the Kao test is used to achieve the results stated in Table 5 below.

Table 5. Results of Kao cointegration tests.

\begin{tabular}{ccc}
\hline ADF & T-statistic & Probability \\
& -2.897320 & 0.0019 \\
\hline
\end{tabular}

Source: Author based on the results obtained on EViews 9.

The results of this test show that the probability associated with the T-statistic is 0.0019; this result does not allow us to accept the null hypothesis of the absence of cointegration. Thus, there is a cointegration relationship between credit 
risk measured by nonperforming loans, return on equity, exports, the ratio of loans to bank assets, inflation, interest and the intermediation rate. Consequently, the integration of the same order [I (1)] of the model variables and the presence of a long-term relationship between the variables allow the use of the dynamic least squares technique to highlight the long-term relationships between nonperforming loans and the explanatory variables.

\section{Results and Discussion}

The presentation of the results and the discussion are addressed in this section. The estimation of the model by the dynamic ordinary least squares method yields the different results summarized in Table 6.

Table 6. Results of the estimation of specific factors CEMAC banks.

\begin{tabular}{|c|c|c|}
\hline Variables & Coefficient & Standard error \\
\hline ROA & $-2.2165^{\star * *}$ & 0.5517 \\
\hline RFA & 60.8024 & 23.9062 \\
\hline RPA & $0.0701^{* *}$ & 0.0650 \\
\hline $\mathrm{RCD}$ & $0.0999 * * *$ & 0.0330 \\
\hline \multicolumn{3}{|c|}{ Wald chi2 $=48.45$} \\
\hline \multicolumn{3}{|c|}{$R$-squared $=0.77$} \\
\hline \multicolumn{3}{|c|}{ Adj $R$-squared $=0.48$} \\
\hline \multicolumn{3}{|c|}{$\begin{array}{c}\text { Note }(* * *) \text { and }(* *) \text { denote the significance of the coefficient } \\
\text { at the thresholds of } 1 \% \text { and } 5 \% \text {, respectively. }\end{array}$} \\
\hline
\end{tabular}

Source: Author's calculation based on data from COBAC reports.

Three results are obtained from the estimates. First, the RCD variable has a positive and significant effect on nonperforming loans from banks at the $1 \%$ threshold. This result suggests that with the growth of deposits, banks engage in extensive lending, which leads to an increase in bank lending relative to deposits. Such behavior leads banks to grant loans to low-quality borrowers, increasing the risk of the loan portfolio and the level of nonperforming loans. This result converges with those of Swamy (2012) and Ahmad and Bashir (2013). A negative and significant relationship between ROA and PNP is also shown, which is explained by mismanagement leading to riskier activities and poor performance. This result is consistent with the results of Louzis et al. (2012) and Radivojevic and Jovovic (2017). Finally, a higher loan-to-asset ratio represents a high level of credit and an increasing likelihood of credit risk. This indicates that the increase in loans increases the level of nonperforming loans, as found by Klein (2013) and Ekanayake and Azeez (2015). These results are consistent with the argument that poor management leads to riskier activities and poor performance. On the other hand, banks that are in a competitive situation can increase loans without too much demand, which can reduce the quality of the loan and therefore increase non-performing loans. Indeed, the information asymmetry between bor- 
rowers and banks often leads to "adverse selection" and "moral hazard", which leads banks to grant very risky loans (Wang, 2019). Thus, we note that variables such as: the return on assets (ROA), the intermediation ratio (RCD) and the ratio of loans to total assets (RPA) explain the increase in bad debts of banks in the CEMAC.

\section{Conclusion and Implications of Economic Policies}

Managing the factors that increase nonperforming loans is a critical issue for the healthy survival of banks. Therefore, knowing these factors is important. The objective of this study was to determine the specific factors of nonperforming loans of CEMAC banks. To do so, we used panel data for the period 2004-2017 and the dynamic ordinary least squares method. The results obtained generally show that nonperforming loans affect the portfolios of CEMAC banks.

The hypothesis supported by this study is verified in that the results found affirm that the increase in nonperforming loans is linked to the specific factors of CEMAC banks.

It would be desirable to have electronic platforms to verify whether an asset has been used as collateral by a client to borrow money from other financial institutions. It would also be desirable for banks to invest in strong credit information systems to reduce information gaps and increase access to complete, accurate and reliable information about borrowers. In addition, this problem can be studied with a focus on individual countries to control the type of factor according to the national context.

\section{Conflicts of Interest}

The author declares no conflicts of interest regarding the publication of this paper.

\section{References}

Adebola, S. S., Wan Yusoff, W., \& Dahalan, J. (2011). An ARDL Approach to the Determinants of Nonperforming Loans in Islamic Banking System in Malaysia. Kuwait Chapter of Arabian Journal of Business and Management Review, 1, 20-30.

Ahmad, F., \& Bashir, T. (2013). Explanatory Power of Macroeconomic Variable as Determinants of NPL: Evidence from Pakistan. World Applied Sciences Journal, 22, 243-255.

Akerlof, G. A. (1970). The Market for "Lemons": Quality Uncertainty and the Market Mechanism. The Quarterly Journal of Economics, 84, 488-500. https://doi.org/10.2307/1879431

Barr, R. S., Seiford, L. M., \& Siems, T. F. (1994). Forecasting Bank Failure: A Non-Parametric Frontier Estimation Approach. Recherches Économiques de Louvain/Louvain Economic Review, 60, 417-429.

BEAC (2004). Rapport Annuel 2004 (139 p.). Banque des Etats de l'Afrique Centrale.

Beck, R., Jakubik, P., \& Piloiu, A. (2013). Non-Performing Loans: What Matters in Addition to the Economic Cycle? https://doi.org/10.2139/ssrn.2214971

Berger, A. N., \& De Young, R. (1997). Problem Loans and Cost Efficiency in Commercial 
Banks. Journal of Banking \& Finance, 21, 849-870. https://doi.org/10.1016/S0378-4266(97)00003-4

Chimkono, E. E., Muturi, W., \& Njeru, A. (2016). Effect of Non-Performing Loans and Other Factors on Performance of Commercial Banks in Malawi. International Journal of Economics, Commerce and Management, 4, 549-563.

Commission Bancaire de L'Afrique Centrale (COBAC), Rapport d'activité 2004, 2005, 2006, 2007, 2008, 2009, 2010, 2011, 2012, 2013, 2014, 2015, 2016 et 2017.

De France, B. (2017). Rapport Annuel 2017. Banque de France/Eurosystème.

Dell'Ariccia, G. (2001). Asymmetric Information and the Structure of the Banking Industry. European Economic Review, 45, 1957-1980. https://doi.org/10.1016/S0014-2921(00)00085-4

Ekanayake, E. M. N. N., \& Azeez, A. A. (2015). Determinants of Non-Performing Loans in Licensed Commercial Banks: Evidence from Sri Lanka. Asian Economic and Financial Review, 5, 868-882. https://doi.org/10.18488/journal.aefr/2015.5.6/102.6.868.882

El Ansari, F., \& Benabdellah, M. (2017). Les déterminants des prêts non performants: Etude empirique du secteur bancaire Marocain. Finance \& Finance Internationale, 6, 1-16. https://doi.org/10.12816/0040534

Gertler, M., \& Bernanke, B. (1989). Agency Costs, Net Worth and Business Fluctuations. In Business Cycle Theory (pp. 257-276). Edward Elgar Publishing Ltd.

Ghosh, A. (2015). Banking-Industry Specific and Regional Economic Determinants of Non-Performing Loans: Evidence from US States. Journal of Financial Stability, 20, 93-104. https://doi.org/10.1016/j.jfs.2015.08.004

Kamunge, E. M. (2013). The Effect of Interest Rate Spread on the Level of Non Performing Loans of Commercial Banks in Kenya. Doctoral Dissertation, University of Nairobi.

Kao, C., \& Chiang, M. H. (2001). On the Estimation and Inference of a Cointegrated Regression in Panel data. Advanced in Economics, 15, 179-222. https://doi.org/10.1016/S0731-9053(00)15007-8

Karadima, M., \& Louri, H. (2021). Determinants of Non-Performing Loans in Greece: The Intricate Role of Fiscal Expansion.

Keeton, C. R., Gaudi, B. S., \& Petters, A. O. (2003). Identifying Lenses with Small-Scale Structure. I. Cusp Lenses. The Astrophysical Journal, 598, 138-161. https://doi.org/10.1086/378934

Keeton, W. R. (1999). Does Faster Loan Growth Lead to Higher Loan Losses? Economic Review, Federal Reserve Bank of Kansas City, 84, 57-75.

Keeton, W. R., \& Morris, C. S. (1987). Why Do Banks' Loan Losses Differ. Economic Review, 72, 3-21.

Khan, M. S., Senhadji, A., \& Smith, B. D. (2001). Inflation and Financial Depth. https://doi.org/10.2139/ssrn.879432

Klein, N. (2013). Non-Performing Loans in CESEE: Determinants and Impact on Macroeconomic Performance. International Monetary Fund. https://doi.org/10.2139/ssrn.2247224

Louzis, D. P., Vouldis, A. T., \& Metaxas, V. L. (2012). Macroeconomic and Bank-Specific Determinants of Non-Performing Loans in Greece: A Comparative Study of Mortgage, Business and Consumer Loan Portfolios. Journal of Banking \& Finance, 36, 1012-1027. https://doi.org/10.1016/j.jbankfin.2011.10.012

Makri, V., Tsagkanos, A., \& Bellas, A. (2014). Determinants of Non-Performing Loans: The Case of Eurozone. Panoeconomicus, 61, 193-206.

https://doi.org/10.2298/PAN1402193M 
Mazreku, I., Morina, F., Misiri, V., Spiteri, J. V., \& Grima, S. (2018). Determinants of the Level of Non-Performing Loans in Commercial Banks of Transition Countries. European Research Studies Journal, 21, 3-13. https://doi.org/10.35808/ersj/1040

Mpofu, T. R., \& Nikolaidou, E. (2018). Determinants of Credit Risk in the Banking System in Sub-Saharan Africa. Review of Development Finance, 8, 141-153.

https://doi.org/10.1016/j.rdf.2018.08.001

Njanike, K. (2009). The Impact of Effective Credit Risk Management on Bank Survival. Annals of the University of Petroşani, Economics, 9, 173-184.

Nkusu, M. M. (2011). Nonperforming Loans and Macrofinancial Vulnerabilities in Advanced Economies. International Monetary Fund. https://doi.org/10.2139/ssrn.1888904

Nor, A. M., Ismail, S., \& Abd Rahman, N. H. (2021). Determinants of Non-Performing Loans in Asia: Is Southeast Asia Different? International Journal of Business and Society, 22, 431-442. https://doi.org/10.33736/ijbs.3187.2021

Ozili, P. K. (2015). How Bank Managers Anticipate Non-Performing Loans. Evidence from Europe, US, Asia and Africa. Applied Finance and Accounting, 1, 73-80. https://doi.org/10.11114/afa.v1i2.880

Pesaran, M. H. (2006). Estimation and Inference in Large Heterogeneous Panels with a Multifactor Error Structure. Econometrica, 74, 967-1012. https://doi.org/10.1111/j.1468-0262.2006.00692.x

Rachman, R. A., Kadarusman, Y. B., Anggriono, K., \& Setiadi, R. (2018). Bank-Specific Factors Affecting Non-Performing Loans in Developing Countries: Case Study of Indonesia. The Journal of Asian Finance, Economics, and Business, 5, 35-42. https://doi.org/10.13106/jafeb.2018.vol5.no2.35

Radivojevic, N., \& Jovovic, J. (2017). Examining of Determinants of Non-Performing Loans. Prague Economic Papers, 26, 300-316. https://doi.org/10.18267/j.pep.615

Rajan, R. G. (1994). Why Bank Credit Policies Fluctuate: A Theory and Some Evidence. The Quarterly Journal of Economics, 109, 399-441. https://doi.org/10.2307/2118468

Richard, L., Gauvin, L., \& Raine, K. (2011). Ecological Models Revisited: Their Uses and Evolution in Health Promotion over Two Decades. Annual Review of Public Health, 32, 307-326. https://doi.org/10.1146/annurev-publhealth-031210-101141

Salas, V., \& Saurina, J. (2002). Credit Risk in Two Institutional Regimes: Spanish Commercial and Savings Banks. Journal of Financial Services Research, 22, 203-224. https://doi.org/10.1023/A:1019781109676

Sinkey, J. F., \& Greenawalt, M. B. (1991). Loan-Loss Experience and Risk-Taking Behavior at Large Commercial Banks. Journal of Financial Services Research, 5, 43-59. https://doi.org/10.1007/BF00127083

Skarica, B. (2014). Determinants of Non-Performing Loans in Central and Eastern European Countries. Financial Theory and Practice, 38, 37-59. https://doi.org/10.3326/fintp.38.1.2

Swamy, V. (2012). Impact of Macroeconomic and Endogenous Factors on Non Performing Bank Assets. https://doi.org/10.2139/ssrn.2060753

Upal, M. A. (2009). Predictive Models of Cultural Information Transmission. In Handbook of Research on Agent-Based Societies: Social and Cultural Interactions (pp. 51-59). IGI Global. https://doi.org/10.4018/978-1-60566-236-7.ch004

Wang, K. (2019). Comparative Analysis of Business Management of Chinese and Foreign Commercial Banks-Based on the Perspective of Non-Performing Loans of Commercial Banks. Modern Economy, 10, 108-119. https://doi.org/10.4236/me.2019.101008

Wanjala, K., \& Gachanja, J. N. (2020). Mr Bank Specific Determinants of Nonperforming 
Loans in Kenya. Business Perspective Review, 2, 29-44.

https://doi.org/10.38157/business-perspective-review.v2i1.118

Yanga, E. D. B. (2020). Effect of Credit Risk on the Efficiency of Banks in Member Countries of the Economic and Monetary Community of Central Africa (Cemac). Journal of Economics, 8, 38-49. https://doi.org/10.15640/jeds.v8n4a4 